\section{Presidedress Soil Nitrate Testing Reduces Nitrogen Fertilizer Use and Nitrate Leaching Hazard in Lettuce Production}

\author{
S.J. Breschini and T.K. Hartz ${ }^{1}$ \\ Department of Vegetable Crops, University of California, Davis, CA 95616
}

Additional index words. PSNT, mineral nutrition, tissue testing, Lactuca sativa

\begin{abstract}
Trials were conducted in 15 commercial fields in the central coast region of California in 1999 and 2000 to evaluate the use of presidedress soil nitrate testing (PSNT) to determine sidedress $\mathrm{N}$ requirements for production of iceberg and romaine lettuce (Lactuca sativa $\mathrm{L}$.). In each field a large plot (0.2-1.2 ha) was established in which sidedress $\mathrm{N}$ application was based on presidedress soil $\mathrm{NO}_{3}-\mathrm{N}$ concentration. Prior to each sidedress $\mathrm{N}$ application scheduled by the cooperating growers, a composite soil sample (top $30 \mathrm{~cm})$ was collected and analyzed for $\mathrm{NO}_{3}-\mathrm{N}$. No fertilizer was applied in the PSNT plot at that sidedressing if $\mathrm{NO}_{3}-\mathrm{N}$ was $>20 \mathrm{mg} \cdot \mathrm{kg}^{-1}$; if $\mathrm{NO}_{3}-\mathrm{N}$ was lower than that threshold, only enough $N$ was applied to increase soil available $N$ to $\approx 20 \mathrm{mg} \cdot \mathrm{kg}^{-1}$. The productivity and $N$ status of PSNT plots were compared to adjacent plots receiving the growers' standard $N$ fertilization. Cooperating growers applied a seasonal average of $257 \mathrm{~kg} \cdot \mathrm{ha}^{-1} \mathrm{~N}$, including one to three sidedressings containing $194 \mathrm{~kg} \cdot \mathrm{ha}^{-1} \mathrm{~N}$. Sidedressing based on PSNT decreased total seasonal and sidedress $N$ application by an average of $43 \%$ and $57 \%$, respectively. The majority of the N savings achieved with PSNT occurred at the first sidedressing. There was no significant difference between PSNT and grower $\mathrm{N}$ management across fields in lettuce yield or postharvest quality, and only small differences in crop $\mathrm{N}$ uptake. At harvest, PSNT plots had on average $8 \mathrm{mg} \cdot \mathrm{kg}^{-1}$ lower residual $\mathrm{NO}_{3}-\mathrm{N}$ in the top $90 \mathrm{~cm}$ of soil than the grower fertilization rate plots, indicating a substantial reduction in subsequent $\mathrm{NO}_{3}$ $\mathbf{N}$ leaching hazard. We conclude that PSNT is a reliable management tool that can substantially reduce unnecessary $\mathbf{N}$ fertilization in lettuce production.
\end{abstract}

The use of nitrogen fertilizer is coming under increased scrutiny in many parts of the United States due to concern over nitrate contamination of groundwater. Groundwater nitrate contamination is of particular concern in the coastal valleys of central California, where many wells now exceed the U.S. Environmental Protection Agency drinking water standard of $10 \mathrm{mg} \cdot \mathrm{kg}^{-1} \mathrm{NO}_{3}-\mathrm{N}$. Vegetable production dominates agriculture in these valleys, with lettuce by far the most common crop. Seasonal $\mathrm{N}$ application $>200 \mathrm{~kg} \cdot \mathrm{ha}^{-1}$ is common for lettuce production (Hartz et al., 2000), substantially more than crop $\mathrm{N}$ uptake, and perhaps three times the amount of $\mathrm{N}$ removed in harvested product (Doerge et al., 1991; Zink and Yamaguchi, 1962). Similar imbalance between the amount of $\mathrm{N}$ applied and that removed in harvested product exists for the other common vegetable crops grown in rotation with lettuce in this region.

Such high rates of fertilization are due in part to conflicting research results, and in part to economic relationships. Gardner and Pew (1972, 1974) found that head lettuce yield peaked with Nat $100-150 \mathrm{~kg} \cdot \mathrm{ha}^{-1}$, while Welch et al. (1979) and MacKay and Chipman (1961) reported yield increase up to at least 250 $\mathrm{kg} \cdot \mathrm{ha}^{-1}$. Given the high potential value of

Received for publication 13 Aug. 2001. Accepted for publication 2 Jan. 2002.

${ }^{1}$ E-mail address: hartz@ vegmail.ucdavis.edu sary $\mathrm{N}$ application. PSNT has been widely shown to identify corn fields in which crop

lettuce (frequently exceeding $\$ 10,000$ per ha), exacting market standards for size and appear$\approx \$ 0.80-1.20$ per kilogram) there has been little economic incentive to minimize $\mathrm{N}$ application in the absence of regulatory pressure. Such pressure is now being brought to bear.

Presidedress soil nitrate testing (PSNT) is response to sidedressed $\mathrm{N}$ was unlikely (Fox et al., 1989; Heckman et al., 1995; Magdoff, 1991; Meisinger et al., 1992; Schmitt and Randall, 1994; Spellman et al., 1996). These studies reported that a soil $\mathrm{NO}_{3}-\mathrm{N}$ concentration (top $30 \mathrm{~cm}$ ) greater than $\approx 20 \mathrm{mg} \cdot \mathrm{kg}^{-1}$ when corn was $15 \mathrm{~cm}$ tall (the stage at which sidedressing is usually done) indicated that no sidedress $\mathrm{N}$ was required to achieve maximum yield. Hartz et al. (2000), working in California, found this $20 \mathrm{mg} \cdot \mathrm{kg}^{-1} \mathrm{NO}_{3}-\mathrm{N}$ threshold successfully identified lettuce and celery fields in which sidedress $\mathrm{N}$ application could be delayed or eliminated. They did not attempt to use PSNT to predict sidedress $\mathrm{N}$ requirements in fields below $20 \mathrm{mg} \cdot \mathrm{kg}^{-1}$. The current study was undertaken to evaluate the utility of PSNT as a general $\mathrm{N}$ management technique in lettuce production, regardless of residual soil $\mathrm{NO}_{3}-\mathrm{N}$ concentration. Our main objective was to document the effects of $\mathrm{N}$ management using PSNT on crop yield and quality, $\mathrm{N}$ application, and postseason $\mathrm{NO}_{3}-\mathrm{N}$ leaching potential across a wide range of field conditions and management practices representative of the commercial industry.

\section{Materials and Methods}

Fifteen trials were conducted in commercial lettuce fields in the central coast region of California in 1999 and 2000. These fields were direct seeded from March through July, for harvest June through September (Table 1). Soils varied in texture from sandy loam to clay. A standard planting configuration of two plant rows per $1.0-\mathrm{m}$ raised bed was used. Plant population varied among fields from 56,000 to 72,000 plants/ha. All trials were initially irrigated by sprinklers, with some fields switched to furrow irrigation during head development. In-season precipitation was negligible in all fields. All fields were chosen randomly, without reference to residual soil $\mathrm{NO}_{3}-\mathrm{N}$ concentration.

In the center of each field a single plot was established in which sidedress $\mathrm{N}$ application was based on presidedress soil $\mathrm{NO}_{3}-\mathrm{N}$ level. Prior to each sidedress $\mathrm{N}$ application sched-
Table 1. Location, soil type, and harvest dates for the lettuce trial sites

\begin{tabular}{lllrr}
\hline \hline Field & Field location & \multicolumn{1}{c}{ Soil type } & Planting date & Harvest date \\
\hline \multicolumn{4}{c}{1999} \\
1 & Salinas & clay loam & 23 Apr & 1 July \\
2 & Soledad & clay loam & 25 Mar & 16 June \\
3 & Soledad & silt loam & 21 Mar & 7 June \\
4 & Salinas & clay & 21 Mar & 14 June \\
5 & Castroville & clay loam & 4 June & 12 Aug \\
6 & Chualar & sandy loam & 25 June & 31 Aug \\
7 & Soledad & clay loam & 20 June & 27 Aug \\
8 & Salinas & clay & 18 July & 28 Sept. \\
9 & Salinas & clay loam & 16 July & 24 Sept. \\
10 & Soledad & silt loam & 23 July & 30 Sept. \\
11 & Castroville & clay loam & 15 July & 22 Sept. \\
& & & \\
12 & Pajaro Valley & loam & 22 May & 24 July \\
13 & Pajaro Valley & clay loam & 24 May & 28 July \\
14 & Castroville & clay & 5 July & 6 Sept. \\
15 & Soledad $^{2}$ & silt loam & 15 July & 13 Sept. \\
\hline${ }^{2}$ Romaine $^{2}$ lettuce field; all other fields were planted with iceberg lettuce
\end{tabular}
cultivars. 
uled by the cooperating grower, composite soil samples (top $30 \mathrm{~cm}$ ) were collected in both the PSNT plot and an adjacent plot receiving the grower's standard N regime. Soil was collected in the planted row to avoid sampling concentrated bands of fertilizer applied earlier in the season; for each plot at least 12 soil cores were collected and blended before analysis. Plots ranged in size among fields from $\approx 0.2-$ 1.2 ha. Each plot covered the entire length of the field to ensure that variability in $\mathrm{N}$ status caused by irrigation effects was included.

Soil samples from the PSNT plots were analyzed for $\mathrm{NO}_{3}-\mathrm{N}$ concentration by the "quick test" method described by Hartz et al. (2000). If soil $\mathrm{NO}_{3}-\mathrm{N}$ exceeded $20 \mathrm{mg} \cdot \mathrm{kg}^{-1}$, no sidedress application was made at that time in the PSNT plot. At lower $\mathrm{NO}_{3}-\mathrm{N}$ concentration the amount of sidedress $\mathrm{N}$ applied to the PSNT plot at that sidedressing varied based on the application schedule in Table 2 . This schedule was calculated to bring the top $30 \mathrm{~cm}$ of soil approximately up to the $20 \mathrm{mg} \cdot \mathrm{kg}^{-1} \mathrm{~N}$ threshold level, based on a typical mineral soil bulk density of $1.4 \mathrm{~g} \cdot \mathrm{cm}^{-3}$. Most fields received two sidedress $\mathrm{N}$ applications, typically one following thinning (SD-1), and the second 2-4 weeks later at the "cupping" growth stage (SD-2). Five fields received a third sidedressing, while two fields received only one. Soil $\mathrm{NO}_{3}-\mathrm{N}$ estimates from the "quick test" procedure were compared with $\mathrm{NO}_{3}-\mathrm{N}$ concentration in $2 \mathrm{~N} \mathrm{KCl}$ extracts of field-moist soil analyzed by the diffusion-conductivity technique of Carlson et al. (1990).

Plant N status was evaluated at SD-2 and at harvest. At SD-2 whole, recently expanded leaves, and midribs from such leaves, were collected. At harvest, tissue from harvested heads and from crop residue was collected. After oven drying and grinding the whole leaf, head and residue samples were analyzed for total $\mathrm{N}$ concentration by combustion (CarloErba 1500, Fisons Instruments, Beverly, Mass). Midribs were extracted in $2 \%$ acetic acid and analyzed for $\mathrm{NO}_{3}-\mathrm{N}$ concentration by the method of Carlson et al. (1990). To allow calculation of aboveground biomass $\mathrm{N}$ accumulation, 12 representative whole plants per $\mathrm{N}$ treatment per field were harvested, separated into marketable head and residue, and the dry mass of each determined.

Plots were harvested at commercial maturity by experienced personnel provided by the growers. Data collected included percentage of plants that were marketable, and marketable yield (number of cartons/ha if packaged for fresh market, or bulk mass/ha if harvested for processing into packaged salad mixes). In nine trials in 1999, the effect of $\mathrm{N}$ fertilization on postharvest quality was evaluated on 24

Table 2. Amount of $\mathrm{N}$ applied at sidedressing, based on presidedress soil $\mathrm{NO}_{3}-\mathrm{N}$ concentration.

\begin{tabular}{cc}
\hline $\begin{array}{c}\text { Soil } \mathrm{NO}_{3}-\mathrm{N} \mathrm{range}^{\mathrm{z}} \\
\left(\mathrm{mg} \cdot \mathrm{kg}^{-1}\right)\end{array}$ & $\begin{array}{c}\text { Sidedress N application } \\
\left(\mathrm{kg} \cdot \mathrm{ha}^{-1}\right)\end{array}$ \\
\hline $0-5$ & 90 \\
$5-10$ & 57 \\
$10-15$ & 45 \\
$15-20$ & 22 \\
\hline
\end{tabular}

${ }^{2}$ Estimated by the 'quick test' procedure heads per $\mathrm{N}$ treatment per field. The heads were stored for $10-14 \mathrm{~d}$ at $5{ }^{\circ} \mathrm{C}$, above the optimal storage temperature (Maynard and Hochmuth, 1997), to simulate the stress of improper commercial handling. The heads were then evaluated for visual quality, decay severity, and degree of discoloration from bruising or russet spotting. Visual quality was rated on a scale of 1 to 10 , with 10 being ideal and 5 indicating the limit of marketability. Decay and discoloration were rated on a scale of 1 to 5 , with 1 indicating no decay or discoloration, and 5 indicating severe decay or discoloration.

To document the fate of grower-applied $\mathrm{N}$ in excess of that applied in the PSNT plots, additional soil sampling was conducted at SD1 and at harvest. Samples were collected to 90$\mathrm{cm}$ depth, by $30-\mathrm{cm}$ increments. Twelve soil cores per plot were collected from the planted row. $\mathrm{NO}_{3}-\mathrm{N}$ concentration in $2 \mathrm{~N} \mathrm{KCl}$ extracts of field-moist soil were determined by the method previously described. The change in soil profile $\mathrm{NO}_{3}-\mathrm{N}$ concentration over the growing season was calculated.

The structure of the trials allowed no withinfield statistical comparison. However, to statistically compare PSNT with grower N management across fields an overall ANOVA was performed, using each field as a replication.

\section{Results and Discussion}

Initial (pre-SD-1) soil $\mathrm{NO}_{3}-\mathrm{N}$ concentration ranged from 10 to $59 \mathrm{mg} \cdot \mathrm{kg}^{-1}$, averaging $32 \mathrm{mg} \cdot \mathrm{kg}^{-1}$ (Table 3). Cooperating growers applied a seasonal average of $\mathrm{N}$ at $257 \mathrm{~kg} \cdot \mathrm{ha}^{-1}$, including one to three sidedressings containing an average of $194 \mathrm{~kg} \cdot \mathrm{ha}^{-1} \mathrm{~N}$. By contrast, total $\mathrm{N}$ applied in PSNT plots was $43 \%$ lower, with a reduction in sidedress $\mathrm{N}$ of $57 \%$. The majority of N savings in the PSNT plots occurred at SD- 1 ; in 11 of the 15 trials, SD- 1 was eliminated; two fields received no sidedress $\mathrm{N}$ at all. $\mathrm{NO}_{3}-\mathrm{N}$ concentration in irrigation water varied among sites from $4-16 \mathrm{mg} \cdot \mathrm{kg}^{-1}$. Assuming that in-season irrigation was $\approx 25-30$ $\mathrm{cm}$ (Jackson et al., 1996), $\mathrm{NO}_{3}-\mathrm{N}$ contained in the water was modest, averaging $<25 \mathrm{~kg} \cdot \mathrm{ha}^{-1}$.

Despite the large difference in fertilizer application at SD-1, PSNT and grower plots had similar midrib $\mathrm{NO}_{3}-\mathrm{N}$ at $\mathrm{SD}-2$, averaging 7.7 and $7.8 \mathrm{~g} \cdot \mathrm{kg}^{-1}$, respectively. Most fields were above the $6 \mathrm{~g} \cdot \mathrm{kg}^{-1}$ sufficiency level for California-grown lettuce suggested by Lorenz and Tyler (1983). In fields 3 and 8, midrib $\mathrm{NO}_{3}-\mathrm{N}$ concentration was low for both grower and PSNT plots (averaging 3.1 and $3.4 \mathrm{~g} \cdot \mathrm{kg}^{-1}$, respectively), but Ndid not appear to be growthlimiting since whole-leaf total $\mathrm{N}$ in both plots in both fields was substantially above the 30 $\mathrm{g} \cdot \mathrm{kg}^{-1}$ sufficiency standard suggested by Lorenz and Tyler (1983). Across fields, mean whole-leaf N at SD-2 was 44 and $43 \mathrm{~g} \cdot \mathrm{kg}^{-1}$ in grower and PSNT plots, respectively. The diagnostic value of midrib $\mathrm{NO}_{3}-\mathrm{N}$ at this growth stage was questionable, since it was not correlated $(P=0.05)$ to concurrently measured soil $\mathrm{NO}_{3}-\mathrm{N}$ or whole-leaf total N. Both plots in all fields had total $\mathrm{N}$ concentration in harvested heads above the $25 \mathrm{~g} \cdot \mathrm{kg}^{-1}$ sufficiency level of Lorenz and Tyler (1983).

Total aboveground biomass $\mathrm{N}$ accumulation in the grower plots averaged only 5-6 $\mathrm{kg} \cdot \mathrm{ha}^{-1}$ higher than the PSNT plots despite the application of an additional $110 \mathrm{~kg} \cdot \mathrm{ha}^{-1} \mathrm{~N}$, an exceedingly low uptake efficiency. Romaine lettuce averaged only $107 \mathrm{~kg} \cdot \mathrm{ha}^{-1} \mathrm{~N}$ in the grower plots compared to $130 \mathrm{~kg} \cdot \mathrm{ha}^{-1} \mathrm{~N}$ for iceberg lettuce.

Overall, there was no significant difference in marketable yield between the PSNT

Table 3. Soil $\mathrm{NO}_{3}-\mathrm{N}$ concentration at sidedress 1 (SD-1), number of sidedress $\mathrm{N}$ applications, and seasonal $\mathrm{N}$ application rates.

\begin{tabular}{|c|c|c|c|c|c|c|}
\hline \multirow[b]{2}{*}{ Field } & \multirow{2}{*}{$\begin{array}{l}\text { Soil } \mathrm{NO}_{3}-\mathrm{N}^{2} \\
\text { at SD-1 }\end{array}$} & \multirow{2}{*}{$\begin{array}{l}\text { No. of } \\
\text { sidedress } \\
\text { applications }\end{array}$} & \multicolumn{2}{|c|}{$\begin{array}{l}\text { Total seasonal N } \\
\left(\mathrm{kg} \cdot \mathrm{ha}^{-1}\right)^{\mathrm{y}}\end{array}$} & \multicolumn{2}{|c|}{$\begin{array}{c}\text { Total sidedress N } \\
\left(\mathrm{kg} \cdot \mathrm{ha}^{-1}\right)^{\mathrm{x}}\end{array}$} \\
\hline & & & Grower & PSNT & Grower & PSNT \\
\hline \multicolumn{7}{|c|}{1999} \\
\hline 1 & 27 & 3 & 365 & 198 & 331 & $163^{x}$ \\
\hline 2 & 18 & 2 & 380 & 213 & 336 & $168^{x}$ \\
\hline 3 & 37 & 3 & 240 & 138 & 213 & 111 \\
\hline 4 & 10 & 3 & 304 & 257 & 235 & $190^{\mathrm{w}}$ \\
\hline 5 & 26 & 1 & 178 & 57 & 136 & $17^{\mathrm{x}}$ \\
\hline 6 & 59 & 3 & 309 & 131 & 180 & 0 \\
\hline 7 & 39 & 2 & 343 & 161 & 230 & 44 \\
\hline 8 & 15 & 2 & 222 & 163 & 161 & 104 \\
\hline 9 & 26 & 2 & 282 & 146 & 247 & $111^{\mathrm{x}}$ \\
\hline 10 & 53 & 2 & 232 & 126 & 106 & 0 \\
\hline 11 & 55 & 1 & 195 & 77 & 153 & $37^{x}$ \\
\hline \multicolumn{7}{|c|}{2000} \\
\hline 12 & 29 & 2 & 134 & 45 & 134 & 45 \\
\hline 13 & 20 & 2 & 185 & 141 & 134 & 90 \\
\hline 14 & 43 & 2 & 231 & 164 & 134 & 67 \\
\hline 15 & 26 & 3 & 258 & 185 & 187 & $115^{\mathrm{v}}$ \\
\hline Mean & 32 & & 257 & 147 & 194 & 84 \\
\hline
\end{tabular}

${ }^{2} \mathrm{NO}_{3}-\mathrm{N}$ concentration by laboratory analysis.

${ }^{y}$ Represents all $\mathrm{N}$ applications, including preplant fertilization and early season water-run applications.

xIncludes late-season water-run application in addition to sidedressing.

${ }^{\text {w Received }} 56 \mathrm{~kg} \cdot \mathrm{ha}^{-1} \mathrm{~N}$ at SD-3 through application error.

${ }^{\mathrm{V}}$ Received $48 \mathrm{~kg} \cdot \mathrm{ha}^{-1} \mathrm{~N}$ at SD-3 through application error. 
and grower treatments (Table 4). In individual fields either the PSNT or grower plots had as much as a $17 \%$ yield advantage, but these differences could be attributed to within-field spatial variability in vigor and plant population rather than an $\mathrm{N}$ response. The percentage of plants harvested was similar between treatments, and tissue $\mathrm{N}$ levels were generally well above established sufficiency standards.

There were no $\mathrm{N}$ treatment effects on postharvest quality (Table 4). Visual quality of the heads declined substantially during postharvest storage, but was still above the marketability threshold. The incidence of decay and discoloration was slight in most fields.

The $\mathrm{NO}_{3}-\mathrm{N}$ "quick test" provided a reasonable estimate of soil $\mathrm{NO}_{3}-\mathrm{N}$ across the wide range of concentration encountered in this study ( $\mathrm{r}=0.93$, Fig. 1 ). While clearly less accurate than laboratory analysis, the quick test allowed timely, on-farm estimation of soil $\mathrm{NO}_{3}-\mathrm{N}$ at relatively low cost (the $\mathrm{NO}_{3}-\mathrm{N}$ test strips are $<\$ 0.50$ each). The $20 \mathrm{mg} \cdot \mathrm{kg}^{-1} \mathrm{NO}_{3}$ $\mathrm{N}$ threshold employed was robust enough to accommodate the degree of error associated with the quick test procedure, and spatial variability of soil $\mathrm{NO}_{3}-\mathrm{N}$.

From SD-1 to harvest, PSNT plots showed a large decline in $\mathrm{NO}_{3}-\mathrm{N}$ in the upper $30 \mathrm{~cm}$ of soil $\left(>12 \mathrm{mg} \cdot \mathrm{kg}^{-1}\right)$, while the decline in grower plots was only $5 \mathrm{mg} \cdot \mathrm{kg}^{-1}$. Grower plots showed an increase in soil $\mathrm{NO}_{3}-\mathrm{N}$ in the $30-90 \mathrm{~cm}$ region while PSNT plots showed a decline. Over the entire 0-90 cm soil profile the grower plots were enriched by an average of $3 \mathrm{mg} \cdot \mathrm{kg}^{-}$ ${ }^{1} \mathrm{NO}_{3}-\mathrm{N}$, while the PSNT plots showed a decline of $5 \mathrm{mg} \cdot \mathrm{kg}^{-1}$; this difference was significant at $P=0.05$.

Nitrogen rates used by the cooperating growers were clearly higher than necessary to achieve maximum lettuce yield and quality. Despite a number of studies that suggested maximum lettuce yields could be obtained with $100-150 \mathrm{~kg} \cdot \mathrm{ha}^{-1} \mathrm{~N}$ (Gardner and Pew, 1972, 1974; Knott and Tavernetti, 1944; Lorenz and Minges, 1942), California growers are hesitant to use such conservative Nrates. PSNT offers an objective mechanism to tailor sidedress $\mathrm{N}$ application to field-specific conditions.

Hartz et al. (2000) found a $20 \mathrm{mg} \cdot \mathrm{kg}^{-1}$ PSNT threshold to be effective in identifying fields in which sidedressing could be delayed or eliminated without affecting crop yield. They did not attempt to use PSNT to determine sidedress rates in fields below the $\mathrm{NO}_{3}-\mathrm{N}$ threshold level. The current study found that adjusting $\mathrm{N}$ sidedress application to bring soil $\mathrm{NO}_{3}-\mathrm{N}$ up to the $20 \mathrm{mg} \cdot \mathrm{kg}^{-1}$ threshold maintained lettuce productivity and quality. Neither of these PSNT studies was structured to include an $\mathrm{N}$-deficient treatment; consequently, the $20 \mathrm{mg} \cdot \mathrm{kg}^{-1} \mathrm{NO}_{3}-\mathrm{N}$ threshold employed may be higher than necessary. Further work is warranted to evaluate that issue. However, widespread adoption of the PSNT technique as employed here could substantially reduce industry-wide $\mathrm{N}$ use, perhaps by $40 \%$ or more.

Midrib $\mathrm{NO}_{3}-\mathrm{N}$ testing to determine crop $\mathrm{N}$ status is widely used by commercial lettuce growers. This study calls into question the
Table 4. Effect of $\mathrm{N}$ treatment on lettuce yield and postharvest quality.

\begin{tabular}{|c|c|c|c|c|c|c|c|c|c|}
\hline \multirow[b]{2}{*}{ Field } & \multirow[b]{2}{*}{$\begin{array}{c}\mathrm{N} \\
\text { treatment }\end{array}$} & \multicolumn{3}{|c|}{$\begin{array}{c}\text { Marketable yield }{ }^{2} \\
\text { (cartons/ha) }\end{array}$} & \multirow[b]{2}{*}{$\begin{array}{c}\text { Bulk mass } \\
\left(\mathrm{kg} \cdot \mathrm{ha}^{-1}\right)\end{array}$} & \multirow[b]{2}{*}{$\begin{array}{c}\% \text { of plants } \\
\text { harvested }\end{array}$} & \multicolumn{3}{|c|}{ Postharvest rating } \\
\hline & & $24 \mathrm{~s}^{\mathrm{y}}$ & $30 s^{y}$ & Total & & & $\begin{array}{r}\text { Visual } \\
\text { quality }\end{array}$ & Decay & Discoloration \\
\hline & & & & & 1999 & & & & \\
\hline \multirow[t]{2}{*}{1} & Grower & 2,380 & & 2,380 & & 78 & 6.8 & 1.8 & 1.3 \\
\hline & PSNT & 2,207 & & 2,207 & & 74 & 6.7 & 1.5 & 1.5 \\
\hline \multirow[t]{2}{*}{2} & Grower & 1,878 & 185 & 2,063 & & 81 & 7.1 & 1.3 & 1.8 \\
\hline & PSNT & 1,804 & 181 & 1,985 & & 80 & 7.2 & 1.3 & 1.8 \\
\hline \multirow[t]{2}{*}{3} & Grower & 2,100 & 227 & 2,327 & & 90 & 7.0 & 2.1 & 2.5 \\
\hline & PSNT & 2503 & 230 & 2,733 & & 94 & 7.1 & 1.9 & 2.3 \\
\hline \multirow[t]{2}{*}{4} & Grower & 1,470 & 801 & 2,271 & & 86 & 6.9 & 1.6 & 1.6 \\
\hline & PSNT & 1,638 & 541 & 2,179 & & 82 & 6.8 & 1.8 & 1.5 \\
\hline \multirow[t]{2}{*}{5} & Grower & 2,503 & & 2,503 & & 76 & 6.5 & 2.1 & 1.7 \\
\hline & PSNT & 2,427 & & 2,427 & & 72 & 7.1 & 1.9 & 2.0 \\
\hline \multirow[t]{2}{*}{6} & Grower & & & & 36,800 & & & & \\
\hline & PSNT & & & & 38,800 & & & & \\
\hline \multirow[t]{2}{*}{7} & Grower & 2,530 & & 2,530 & & 84 & 6.1 & 2.5 & 2.3 \\
\hline & PSNT & 2,691 & & 2,691 & & 81 & 6.8 & 2.3 & 2.1 \\
\hline \multirow[t]{2}{*}{8} & Grower & 2,009 & 304 & 2,313 & & 84 & & & \\
\hline & PSNT & 1,913 & 282 & 2,195 & & 83 & & & \\
\hline \multirow[t]{2}{*}{9} & Grower & 1,161 & & 1,161 & & 47 & 6.4 & 2.3 & 2.2 \\
\hline & PSNT & 1,161 & & 1,161 & & 50 & 6.6 & 2.1 & 2.1 \\
\hline \multirow[t]{2}{*}{10} & Grower & 2,570 & 10 & 2,580 & & 87 & 6.9 & 2.0 & 2.0 \\
\hline & PSNT & 2,392 & 57 & 2,449 & & 89 & 6.7 & 1.7 & 2.1 \\
\hline \multirow[t]{3}{*}{11} & Grower & & & & 36,500 & & 7.3 & 1.8 & 1.0 \\
\hline & PSNT & & & & 33,500 & & 7.2 & 1.5 & 1.0 \\
\hline & & & & & 2000 & & & & \\
\hline \multirow[t]{2}{*}{12} & Grower & 2,318 & & 2,318 & & 93 & & & \\
\hline & PSNT & 2,587 & & 2,587 & & 95 & & & \\
\hline \multirow[t]{2}{*}{13} & Grower & 2,184 & & 2,184 & & 81 & & & \\
\hline & PSNT & 2,120 & & 2,120 & & 90 & & & \\
\hline \multirow[t]{2}{*}{14} & Grower & & & & 41,800 & & & & \\
\hline & PSNT & & & & 46,900 & & & & \\
\hline \multirow[t]{2}{*}{15} & Grower & 2,829 & & 2,829 & & 99 & & & \\
\hline & PSNT & 2,884 & & 2,884 & & 99 & & & \\
\hline \multirow[t]{3}{*}{ Mean } & Grower & 2,161 & 127 & 2,288 & 38,400 & 82 & 6.7 & 1.9 & 1.8 \\
\hline & PSNT & 2,194 & 108 & 2,302 & 39,700 & 83 & 6.9 & 1.8 & 1.8 \\
\hline & & NS & NS & NS & NS & NS & NS & NS & NS \\
\hline
\end{tabular}

${ }^{2}$ Cartons/ha if boxed for fresh market; bulk weight if harvested for processing into salad mixes. ${ }^{y}$ Head count per carton.

${ }^{\text {ss } P S N T}$ and grower plots not significantly different across fields at $P=0.05$.

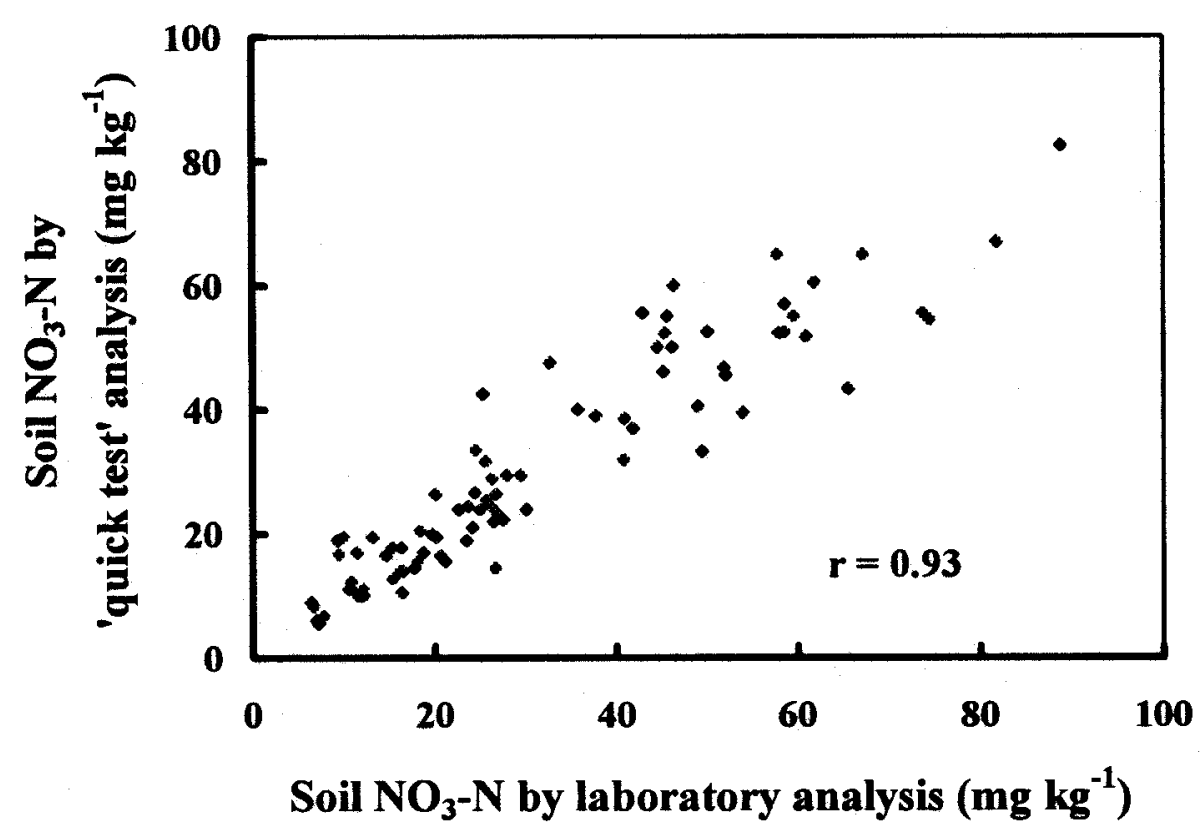

Fig. 1. Accuracy of the soil $\mathrm{NO}_{3}-\mathrm{N}$ "quick test" procedure for estimation of soil $\mathrm{NO}_{3}-\mathrm{N}$ concentration. 
value of that technique to determine fieldspecific sidedress $\mathrm{N}$ requirements. At SD-1, the point at which the majority of $\mathrm{N}$ savings was realized by PSNT, plants are so small that insufficient tissue is available to collect the standard midrib sample. Furthermore, at SD2 there was no correlation between midrib $\mathrm{NO}_{3}-\mathrm{N}$ and currently available soil $\mathrm{NO}_{3}-\mathrm{N}$. Clearly, factors other than soil $\mathrm{N}$ availability have profound effects on midrib $\mathrm{NO}_{3}-\mathrm{N}$, severely limiting the value of that analysis at this early growth stage. We conclude, as did Hartz et al. (2000) and Pritchard et al. (1995), that soil testing is more appropriate than midrib testing to evaluate field $\mathrm{N}$ status, at least until SD-2.

Much of the excess fertilization in grower plots occurred early in the growing season; most of the $\mathrm{N}$ reduction in PSNT plots occurred at SD-1. Since more than $65 \%$ of lettuce $\mathrm{N}$ uptake occurs in the final third of the growing season (Gardner and Pew, 1979; Zink and Yamaguchi, 1963) heavy early-season applications are inherently inefficient. The similarity between $\mathrm{N}$ treatments in tissue $\mathrm{N}$ concentration at SD-2, and in biomass $\mathrm{N}$ accumulation, suggested that lettuce plants do not take up much of the fertilizer that is routinely applied early in the season.

Lettuce is an ideal crop on which to employ PSNT because lettuce has modest $\mathrm{N}$ requirements; biomass $\mathrm{N}$ accumulation averaged $<130$ $\mathrm{kg} \cdot \mathrm{ha}^{-1}$ in the test fields. Other common coolseason vegetables such as broccoli, cauliflower and celery typically contain $>200 \mathrm{~kg} \cdot \mathrm{ha}^{-1} \mathrm{~N}$ at harvest (Doerge et al., 1991; Feigin et al., 1982; Letey et al., 1983; Welch et al., 1985). Effective use of PSNT for those crops may require either a higher soil $\mathrm{NO}_{3}-\mathrm{N}$ threshold, or additional soil nitrate sampling later in the cropping cycle.

Lettuce is a shallowly rooted crop that is irrigated frequently (Jackson and Stivers, 1993). Therefore, substantial $\mathrm{NO}_{3}-\mathrm{N}$ may be leached from the root zone, as shown by the net accumulation of $\mathrm{NO}_{3}-\mathrm{N}$ in the $30-90 \mathrm{~cm}$ section of the soil profile of the grower plots. This accumulation of $\mathrm{NO}_{3}-\mathrm{N}$ parallels the findings of Jackson et al., (1994), who reported that a double-cropped lettuce field lost as much as $150 \mathrm{~kg} \cdot \mathrm{ha}^{-1} \mathrm{~N}$ from nitrate leaching even with conservative fertilization $(\approx 92$ $\mathrm{kg} \cdot \mathrm{ha}^{-1} \mathrm{~N}$ per crop). The net $\mathrm{NO}_{3}-\mathrm{N}$ decline in the top $90 \mathrm{~cm}$ of soil in PSNT plots suggested that subsequent leaching hazard had been substantially reduced, compared to the conventional grower $\mathrm{N}$ management.

In summary, PSNT was shown to be a reliable technique to minimize unnecessary sidedress $\mathrm{N}$ application. If widely adopted by the California industry a significant reduction in overall $\mathrm{N}$ usage could be achieved, with substantial reduction in groundwater pollution potential.

\section{Literature Cited}

Carlson, R.M., R.L.Cabrera, J.L. Paul, J. Quick, and R.V. Evans. 1990. Rapid determination of ammonium and nitrate in soil and plant tissue extracts. Comm. Soil. Sci. Plant. Anal. 21(1316):1519-1529.

Doerge, T.A., R.L. Roth, and B.R. Gardner. 1991. Nitrogen fertilizer management in Arizona. Coll. of Agr., Univ. of Arizona, Tucson.

Feigin, A.J., J. Letey, and W.M. Jarrell. 1982. Celery response to type, amount and method of $\mathrm{N}$ fertilizer application under drip irrigation. Agron. J. 74:971-977.

Fox, R.H., G.W. Roth, K.V. Iversen, and W.P. Pickielek. 1989. Soil and tissue nitrate tests compared for predicting soil nitrogen availability to corn. Agron. J. 81:971-974.

Gardner, B.R. and W.D. Pew. 1972. Response of fall grown head lettuce to nitrogen fertilization. Univ. of Arizona Agr. Expt. Sta. Tech. Bul. 199.

Gardner, B.R. and W.D. Pew. 1974. Response of spring grown head lettuce to nitrogen fertilizer. Univ. of Arizona Agr. Expt. Sta. Bul. 210.

Gardner, B.R. and W.D. Pew. 1979. Comparison of various nitrogen sources for the fertilization of winter-grown head lettuce. J. Amer. Soc. Hort. Sci. 104:534-536

Hartz, T.K., W.E. Bendixen, and L. Wierdsma. 2000. The value of presidedress soil nitrate testing as a nitrogen management tool in irrigated vegetable production. HortScience 35:651656.

Heckman, J.R., W.T. Hlubik, D.J. Prostak, and J.W. Paterson. 1995. Pre-sidedress soil nitrate test for sweet corn. HortScience 30:1033-1036.

Jackson, L.E. and L.J. Stivers. 1993. Root distribution of lettuce under commercial production: implications for crop uptake of nitrogen. Biol Agr. Hort. 9:273-293.

Jackson, L.E., L.J. Stivers, B.T. Warden, and K.K. Tanji. 1994. Crop nitrogen utilization and soil nitrate loss in a lettuce field. Fert. Res. 37:93105.

Jackson, L., K. Mayberry, F. Laemmlen, S. Koike,
K. Schulbach, and W. Chaney. 1996. Iceberg lettuce production in California. Univ. Calif. Coop. Ext. Bul. 7215.

Knott, J.E., and A.A. Tavernetti. 1944. Production of head lettuce in California. California Coop. Ext. Circ. 128.

Letey, J., W.M. Jarrell, N. Valoras, and R. Beverly. 1983. Fertilizer application and irrigation management of broccoli production and fertilizer use efficiency. Agron. J. 75:502-507.

Lorenz, O.A. and P.A. Minges. 1942. Nutrient absorption by a summer crop of lettuce in Salinas valley, California. J. Amer. Soc. Hort. Sci. 40:523-527.

Lorenz, O.A. and K.B. Tyler. 1983. Plant tissue analysis of vegetable crops, p. 24-29. In: H.M. Reisenaur (ed.). Soil and plant tissue testing in California. Univ. Calif. Coop. Ext. Bul. 1879.

Mackay, D.C. and E.W. Chipman. 1961. The response of several vegetables to applied nitrogen, phosphorus, and potassium on a sphagnum peat soil. Soil Sci. Soc. Amer. Proc. 25:309-312.

Magdoff, F. 1991. Understanding the Magdoff presidedress nitrate test for corn. J. Prod. Agr. 4:297-305.

Maynard, D.N. and G.J. Hochmuth. 1997. Knott's handbook for vegetable growers. 4th ed. Wiley, New York.

Meisinger, J.J., V.A. Bandel, J.S. Angle, B.E. O'Keefe, and C.M. Reynolds. 1992. Presidedress nitrate test evaluation in Maryland. Soil Sci. Soc. Amer. J. 56:1527-1532.

Pritchard, K.H., T.A. Doerge, and T.L. Thompson. 1995. Evaluation of in-season nitrogen tests for drip irrigated leaf and romaine lettuce. Commun. Soil Sci. Plant Anal. 26:237-257.

Schmitt, M.A. and G.W. Randall. 1994. Developing a soil nitrogen test for improving recommendations for corn. J. Prod. Agr. 7:328-334.

Spellman, D.E., A. Rongni, D.G. Westfall, R.M. Waskom, and P. Soltanpour. 1996. Pre-sidedress nitrate soil testing to manage nitrogen fertility in irrigated corn in a semi-arid environment. Commun. Soil Sci. Plant Anal. 27:561-574.

Welch, N.C., K.B. Tyler, and D. Ririe. 1979. Nitrogen stabilization in the Pajaro valley in lettuce, celery, and strawberries. California Agr. 33(9):12-13.

Welch, N.C., K.B. Tyler, and D. Ririe. 1985. Nitrogen rates and nitrapyrin influence on yields of Brussels sprouts, cabbage, cauliflower and celery. HortScience 20:1110-1112.

Zink, F.W. and M. Yamaguchi. 1962. Studies on the growth rate and nutrient absorption of head lettuce. Hilgardia 32:471-500.

Zink, F.W. and M. Yamaguchi. 1963. Head lettuce growth and nutrient absorption studies indicate need for reevaluation of fertilizer practices. California Agr. 17(3):13-14. 